\title{
New players in the preventive treatment of migraine
}

\author{
Dimos D. Mitsikostas ${ }^{1 *}$ and Alan M. Rapoport ${ }^{2,3}$
}

\begin{abstract}
Migraine is a common, chronic disorder of the brain causing much disability, as well as personal, familial and societal impact. Several oral preventive agents are available in different countries for the prevention of migraine, but none have performed better than $50 \%$ improvement in $50 \%$ of patients in a clinical trial. Additionally, each has various possible adverse events making their tolerability less than optimal. Recently, three monoclonal antibodies targeting the calcitonin gene-related peptide (CGRP) ligand (LY2951742, ALD403 and TEV-48125) and one targeting the CGRP receptor (AMG 334) have completed phase 2 trials, and the results have been reported. These early results show them all to be somewhat more effective than placebo, with no serious adverse events. Three have been studied for episodic migraine, and only TEV-48125 has been studied for both high frequency episodic and chronic migraine. Moreover, preliminary data suggests that neurostimulation is effective in migraine treatment, including stimulation of the sphenopalatine ganglion, transcutaneous supraorbital and supratrochlear nerve, and transcutaneous vagus nerve. In this article, these innovative therapies will be reviewed.
\end{abstract}

Keywords: Migraine, Cluster headache, Prevention, CGRP, Monoclonal antibodies, Neurostimulation, Neuromodulation, Vagus nerve stimulation, Supraorbital and supratrochlear nerve stimulation

\section{Background}

Migraine is a common, chronic neurovascular disorder of the brain with cranial autonomic findings. It is characterized by recurrent, severe attacks of headaches often associated with other symptoms and much disability, as well as personal, familial and societal impact. It affects approximately $12 \%$ of the general population in Western countries, and affects three times more women than men [1]. Migraine disability is related to the frequency and severity of attacks together with the number and type of existing comorbidities. Mood disorders, obesity and medication overuse are the most common co-occurring chronic disorders that significantly amplify the impact of migraine on the individual $[2,3]$.

Migraine attacks are episodic and average 1-3 times per month in most migraineurs. Chronic migraine is defined as headaches on at least 15 days per month for at least 3 months in patients with a history of episodic migraine. Additionally, patients must present features of migraine on

\footnotetext{
* Correspondence: dimosmitsikostas@icloud.com

${ }^{1}$ Neurology Department, Athens Naval Hospital, 70 Dinokratous Street, 11521 Athens, Greece

Full list of author information is available at the end of the article
}

at least 8 days per month. Up to $30 \%$ of migraineurs have an aura preceding or coexisting with the headache, which is usually a visual aberration lasting about 20 minutes, but could be paresthesias on one side of the body or speech arrest [4].

Patients with episodic migraine can remit, remain unchanged, or progress to high-frequency episodic or chronic migraine over time. Chronic migraine is associated with a substantially greater personal and societal burden, an increased number of comorbidities, and patients may develop progressive brain abnormalities [5-7]. Migraine is a serious and widespread health problem as measured by years lived with disability (YLDs) and is considered the sixth highest cause of disability worldwide, while medication overuse headaches follow at eighteenth [8]. By adding these two conditions together, headache becomes the third most common cause of disability measured in YLDs worldwide [9].

All migraineurs require acute care treatment, and up to $40 \%$ of episodic migraineurs could benefit from preventive therapy; but few undertake it. Poor quality of life is one of the various appropriate reasons to start a patient on migraine preventive therapy. All patients with 
chronic migraine should be offered prevention to attempt to reduce the number and severity of their headache days. Currently, oral pharmaceutical agents are recommended as the first choice for preventive migraine treatment worldwide and invasive treatments are suggested only occasionally [10-12].

The main goals of migraine preventive treatment include: reducing headache frequency, severity and intensity; restoring function; and preventing progression to chronic migraine. There is evidence that valproate, topiramate, metoprolol, propranolol, timolol and flunarizine are effective for episodic migraine prevention and should be offered to appropriate migraineurs to reduce migraine attack frequency and severity (level A medications) [10]. Frovatriptan (primarily indicated and usually used for acute care of migraine) is effective for prevention of menstrual migraine (level A), while lamotrigine is ineffective for migraine prevention and should not be used (level A) [10-12]. Although commonly used in clinical practice, amitriptyline does not carry adequate evidence for migraine prevention (only class II studies) [10]. For prevention of chronic migraine (with and without medication overuse) only one treatment is approved in the US by the Food and Drug Administration (FDA) and that is onabotulinumtoxinA. Topiramate studies do show efficacy but there is no approval for this condition [13-15]. Additionally, a variety of behavioral medicine treatments, such as biofeedback training and cognitive restructuring, are available for these patients [16].

\section{Do we need novel migraine preventive treatments?}

Although there are many approved and unapproved preventive treatments for migraine, they are often insufficient to manage migraineurs effectively, even in the right hands. There are issues of efficacy, tolerance, safety, adherence, pharmacophobia and nocebo response, all suggesting the need for better treatments. There are several outcome measures used in clinical trials to qualify the efficacy of migraine prevention. The most common is a decrease in migraine or headache days per month compared to baseline, and the proportion of responders to the treatment, defined as those patients that report more than a $50 \%$ decrease in migraine days per month after a given treatment (the $50 \%$ responder rate). The number needed to treat (NNT; defined as the number of patients who need a specific treatment to prevent one additional bad outcome, e.g. a migraine attack) for responders varies from 4-6 in several randomized trials for migraine prevention (indicating that 4-6 patients suffering from migraine must be treated in order for one to reach a $50 \%$ decrease in migraine days per month). The decrease in migraine days per month after extracting the placebo effect varies from $1.2-1.8[17,18]$. This absolute improvement, not including the placebo effect that indeed exists and improves treatment outcomes in real life, looks very small; there is clearly room for improvement. There is also evidence that migraineurs are very sensitive to adverse events (AEs) of preventive medications and more likely to withdraw from treatment because of AEs in comparison to epileptics, as one meta-analytic study with topiramate showed [19]. Generally, one out of five patients treated with any migraine preventive pharmaceutical agent will discontinue treatment because of tolerability and safety reasons [20], as did one out of twenty patients treated with placebo in randomized controlled studies [21]. In this context, a medication's safety profile matters significantly to migraineurs and impacts adherence considerably [22].

Adherence is poor in migraine preventive treatments, as in most conditions requiring chronic therapy. Only one out of four patients complies with treatment in chronic migraine when it is required for 6 months, and this decreases to one in five when treatment duration increases to 1 year. Adherence is related to drug tolerability and efficacy [23], once again indicating the need for novel and better anti-migraine therapies.

Pharmacophobia refers to the fear of medication. Taken together with the nocebo effect, which refers to the experience of AEs related to patients' negative expectation that a treatment will most likely harm instead of help, these two concepts control treatment adherence and outcome in migraine and other headaches significantly. It is known that one out of twenty headache sufferers discontinues treatment because of the nocebo effect [22]. For all of these reasons, improved therapeutic approaches, including non-pharmaceutical ones, should continue to be researched.

Novel preventive anti-migraine treatments and interventions In the last 10 years, several new acute care and preventive migraine treatments have surfaced, some of them related to the calcitonin gene-related peptide (CGRP). The small molecule CGRP receptor antagonists have been effective, without evidence of vasoconstriction in animals, but there have been issues of safety, thus far preventing further development. In the last few years we have seen the development of four monoclonal antibodies targeting CGRP or its receptor (CGRP-mAbs). Phase 2 trials show promising efficacy data with limited adverse events and almost no serious adverse events.

\section{Monoclonal antibodies to CGRP ligand and receptor}

Although the small molecule agents that target the CGRP receptor are still under investigation, the recent development of humanized antibodies to CGRP and its receptor appear more promising for three important reasons: they are unlikely to cause liver toxicity or other serious AEs; they are biological products with extreme specificity for their target and very long half-lives, compared to oral 
medications; and they may have considerably better tolerability and safety profiles [24].

To demonstrate that CGRP-mAbs will be useful in migraine treatment, four such antibodies have been tested successfully in animal models and are currently in phase 3 trials in the US [25-27]. The major concern is that blocking CGRP, a potent and ubiquitous vasodilator, may cause cardiovascular effects, including medicationinduced hypertension, interactions with the efficacy of anti-hypertensive drugs and inhibition of ischemia-related coronary vasodilatation [28]. Monoclonal antibodies may cause biological effects within other organ systems. Infusion and immunological reactions are also potential adverse events [29]. Another important concern is the long half-lives of mAbs, which prevent immediate clearance in case of severe AEs [24]. Of course, this is also one of its major benefits, as long half-lives prevent the need for frequent dosing. Lastly, the possible development of neutralizing anti-drug antibodies may abolish the effectiveness of the treatment, but this has not been a significant issue thus far in the trials. To eliminate these concerns, several phase 1 studies have been conducted in humans for each of these therapies and show that sustained CGRP inhibition is not associated with hemodynamic or ECG changes, nor have other significant safety concerns emerged [30, 31].

Four humanized, monoclonal antibodies are currently in phase 3 trials for the prevention of episodic or chronic migraine and even cluster headache: ALD403 (Alder Biopharmaceutical, Bothell, WA, USA); LY2951742 (Eli Lilly, Indianapolis, IN, USA); AMG 334 (Amgen, Cambridge, UK); and TEV-48125 (Teva, Petah Tikva, Israel) [32-36] The principal findings of these phase 2 studies are summarized in Table 1. Published data are available for three antibodies: LY2951742; ALD403; and TEV-48125 $[32,33,35,36]$. Data for AMG 334 is based on a presentation at the International Headache Society Congress (IHC) in Valencia, in May 2015 [34]. Some CGRP antibodies have been tested in patients suffering from episodic migraine, others in a wider range of headache frequencies, from high frequency episodic migraine to chronic migraine (Table 1). The primary endpoint was common in all studies of episodic migraine (change in migraine days per month from baseline). TEV-48125 was also tested in chronic migraine using a novel primary endpoint of decrease in the total number of hours per month of headache at 3 months versus baseline [36]. The different frequencies of migraine in these studies, the different types of migraine and the different primary endpoints make it difficult to adequately compare these treatments.

All four episodic migraine studies show the monoclonal antibodies starting to work in 4 weeks versus placebo. The TEV-48125 study shows significance over placebo in less than 1 week [36]. In Table 2, a comparison between CGRP monoclonal antibodies and currently available oral treatments in the prevention of episodic migraine [37] is presented. NNT are comparable. However, these comparisons merely present a rough idea of comparability. Since each trial is different and there are no head-to-head studies, no conclusions can be drawn. Numbers needed to harm (NNH) appear to favor TEV48125, ALD403 and LY2951742. NNTs for treatment discontinuation due to AEs and relative risks for AEs favor LY2951742, ALD403 and TEV-48125 as well [37]. Adverse events specific to CGRP actions (e.g. hypertension and coronary vasodilatation) have not been an issue in these trials. Lastly, the development of antiCGRP antibodies remains to be tested in long-term follow-up studies. In the Teva trials, a few patients had neutralizing antibodies even before starting the trial, the number did not increase after the trial and no significant problems developed in those patients. The other trials had patients with more neutralizing autoantibodies with apparently no deleterious effects. Results from phase 2 studies in episodic migraine showed that patients treated with either ALD403 or LY2951742 developed anti-CGRP222 antibodies within 24 weeks (14 \% and $18 \%$, respectively) [32, 33], indicating that some will develop neutralizing auto-antibodies (NAbs). Experience from biological agents used in multiple sclerosis (MS) shows that about $15 \%$ of patients develop neutralizing auto-antibodies, which decreases biological activity and consequently their therapeutic action [38].

Adherence to treatment is a critical factor in migraine management, but is often underuestimated [23, 39, 40]. Many patients who begin migraine prevention with oral agents no longer take these medications 3-6 months after they start them. One study shows that $73.4 \%, 70.2 \%$ and $67.6 \%$ of 4,634 migraineurs who initiated migraine prevention with antidepressants, anti-epileptics and beta-blockers, respectively, were found non-adherent 6 months later [40]. More than a few factors power adherence, including tolerability and frequency of treatment administration, and both favor CGRP-mAbs; but this has to be proven in long-term follow-up studies.

Overall, CGRP-mAbs look like promising options for migraine and chronic migraine prevention with impressive responder rates, improved safety and tolerability, absence of liver toxicity and long half-lives leading to infrequent dosing. Depending on the results of phase 3 trials, these therapies could become first-line in episodic and chronic migraine prevention. No doubt they will be costly, but if they are effective, prevent disability and frequent visits for emergency care, they may be cost-effective.

Notably, oral CGRP receptor antagonists are still under investigation for acute care and prevention of migraine, with promising results. Telcagepant did not show efficacy over placebo in women suffering from perimenstrual 
Table 1 Monoclonal antibodies target to CGRP pathway in clinical trials phase II for migraine prevention

\begin{tabular}{|c|c|c|c|c|c|c|c|c|c|c|c|c|}
\hline Antibody & Target & $\begin{array}{l}\text { Study size } \\
\text { population } \\
\text { (active vs. } \\
\text { placebo) }\end{array}$ & Inclusion criteria & $\begin{array}{l}\text { Mean baseline } \\
\text { MHD/28d } \\
\text { (active vs. } \\
\text { placebo) }\end{array}$ & $\begin{array}{l}\text { Treatment } \\
\text { duration } \\
\text { (weeks) }\end{array}$ & $\begin{array}{l}\text { Dose, root \& } \\
\text { frequency }\end{array}$ & $\begin{array}{l}\text { Primary } \\
\text { outcome } \\
\text { (change from } \\
\text { baseline) }\end{array}$ & $\begin{array}{l}\text { Active vs. placebo } \\
\text { change of primary } \\
\text { outcome }\end{array}$ & $\begin{array}{l}50 \% \\
\text { responder } \\
\text { rate (NNT) }\end{array}$ & $\begin{array}{l}\text { Dropout } \\
\text { ratio }\end{array}$ & Common AEs & $\begin{array}{l}\text { Anti-drug } \\
\text { antibodies }\end{array}$ \\
\hline $\begin{array}{l}\text { LY2951742 } \\
{[33]}\end{array}$ & CGRP & $\begin{array}{l}218 \\
(108 \text { vs. } 110)\end{array}$ & $\begin{array}{l}\text { Episodic migraine } \\
(4-14 \mathrm{MHD} / 28 \mathrm{~d})\end{array}$ & 6.7 vs. 7.0 & 12 & $\begin{array}{l}150 \text { mg sc; every } \\
2 \text { weeks }\end{array}$ & $\begin{array}{l}\text { MHD/28d } \\
\text { (at 9-12 weeks) }\end{array}$ & $\begin{array}{l}-4.2 \text { vs. }-3.0 \\
(1.2 \text { days difference, } \\
p=0.003)\end{array}$ & $\begin{array}{l}70 \% \text { vs. } \\
45 \%(4.0)\end{array}$ & $12 \%$ & $\begin{array}{l}\text { Erythema; Site } \\
\text { pain; infection; } \\
\text { abdominal pain }\end{array}$ & $18.7 \%$ \\
\hline $\begin{array}{l}\text { ALD403 } \\
{[32]}\end{array}$ & CGRP & $\begin{array}{l}163 \\
\text { (81 vs. 82) }\end{array}$ & $\begin{array}{l}\text { Episodic migraine } \\
\text { (5-14 MHD/28d) }\end{array}$ & 8.4 vs. 8.8 & 12 & $1 \mathrm{~g}$ iv; once & $\begin{array}{l}\text { MHD/28d } \\
\text { (at 5-8 weeks) }\end{array}$ & $\begin{array}{l}-5.6 \text { vs. }-4.6 \text { ( } 1 \text { day } \\
\text { difference, } p=0.03 \text { ) }\end{array}$ & $\begin{array}{l}75 \% \text { vs. } \\
54 \%(4.7)\end{array}$ & $6.2 \%$ & $\begin{array}{l}\text { Tooth abscess; } \\
\text { dizziness; ECG } \\
\text { changes; dry } \\
\text { mouth }\end{array}$ & $14 \%$ \\
\hline $\begin{array}{l}\text { TEV48125 } \\
{[35]}\end{array}$ & CGRP & $\begin{array}{l}297(96,97 \\
\text { vs. 104) }\end{array}$ & $\begin{array}{l}\text { Episodic migraine } \\
\text { (8-14 MHD/28d) }\end{array}$ & 11.4 vs. 11.5 & 12 & $\begin{array}{l}225 \& 675 \mathrm{mg} \mathrm{sc} ; \\
\text { every } 4 \text { weeks }\end{array}$ & $\mathrm{MHD} / 28 \mathrm{~d}$ & $\begin{array}{l}2.64 \text { days difference, } \\
p<0.001\end{array}$ & $\begin{array}{l}59 \% \text { vs. } \\
28 \%(3.2)\end{array}$ & $9.1 \%$ & $\begin{array}{l}\text { Injection site } \\
\text { discomfort; } \\
\text { redness }\end{array}$ & $1 \%$ \\
\hline $\begin{array}{l}\text { TEV } 48125 \\
{[36]}\end{array}$ & CGRP & $\begin{array}{l}264 \text { (175 vs. } \\
89,3 \text { arms) }\end{array}$ & Chronic Migraine & $\begin{array}{l}16.4 \text { vs. } 16.8 \\
(157.7 \text { vs. } \\
169.1 \text { hours/mo) }\end{array}$ & 12 & $\begin{array}{l}225 / 675 \text { \& } \\
900 \text { mg sc; every } \\
4 \text { weeks }\end{array}$ & $\mathrm{HH} / 28 \mathrm{~d}$ & $\begin{array}{l}-67.5 \text { vs. }-37.1 \\
(30.4 \text { hrs difference, } \\
p=0.001 \text { ) }\end{array}$ & NA & $14.4 \%$ & $\begin{array}{l}\text { Injection site; } \\
\text { pruritus }\end{array}$ & $1 \%$ \\
\hline $\begin{array}{l}\text { AMG334 } \\
{[34]}\end{array}$ & $\begin{array}{l}\text { CGRP } \\
\text { receptor }\end{array}$ & 483 (4 arms) & Episodic migraine & 8.7 & 12 & $\begin{array}{l}7,21 \& 70 \mathrm{mg} \mathrm{sc} ; \\
\text { every } 4 \text { weeks }\end{array}$ & $\begin{array}{l}\text { MHD/28d } \\
\text { (at 9-12 weeks) }\end{array}$ & $\begin{array}{l}-3.4 \text { vs. }-2.28 \\
(1.1 \text { day difference, } \\
p=0.021)\end{array}$ & $\begin{array}{l}47 \% \text { vs. } \\
30 \%(5.9)\end{array}$ & NA & $\begin{array}{l}\text { Fatigue; } \\
\text { influenza; } \\
\text { nasopharyngiitis; } \\
\text { arthralgia; back } \\
\text { pain }\end{array}$ & NA \\
\hline
\end{tabular}


Table 2 Comparison between CGRP monoclonal antibodies, transcutaneous supraorbital nerve stimulation and current available oral treatments in the prevention of episodic migraine

\begin{tabular}{llllllllll}
\hline Drug & LY2951742 & $\begin{array}{l}\text { ALD403 } \\
{[32]}\end{array}$ & $\begin{array}{l}\text { TEV48125 } \\
{[35]}\end{array}$ & $\begin{array}{l}\text { AMG334 } \\
{[34]}\end{array}$ & $\begin{array}{l}\text { tSNS } \\
{[42]}\end{array}$ & $\begin{array}{l}\text { Valproate } \\
{[37]}\end{array}$ & $\begin{array}{l}\text { Topiramate } \\
{[37]}\end{array}$ & $\begin{array}{l}\text { Propranolol } \\
{[37]}\end{array}$ & $\begin{array}{l}\text { Amitriptyline } \\
{[37]}\end{array}$ \\
\hline NNT & 4 & 4.7 & 3.2 & 5.9 & 3.8 & 4 & 3 & 4 & 4 \\
NNH & 20 & 20 & $\infty$ & NA & $\infty$ & $7-14$ & $2-17$ & NA & NA \\
Relative risk for AE & 1.07 & 1.09 & 1 & NA & 1 & 1.2 & 1.8 & 2.1 & 1.9 \\
NNT for discontinuation due & $\infty$ & $\infty$ & $\infty$ & NA & $\infty$ & NA & 16 & 16 & 19
\end{tabular}

to $A E$

tSNS: transcutaneous supraorbital nerve stimulation; NNT: number needed to treat; NNH: number needed to harm; AE: adverse event; NA: non applicable; $\infty$ : NNH, same percentage of patients experienced any adverse event in both placebo and drug treated patients; NNTs for discontinuation due to adverse events, no patient treated with the drug discontinued because of adverse event

migraine [41], but in another placebo-controlled trial for migraine prevention, telcagepant resulted in a larger reduction from baseline than placebo for mean monthly headache days (month 1: $140 \mathrm{mg},-2.9 ; 280 \mathrm{mg},-3.1$; placebo, $-1.7 ; P<0.05)$ and migraine/probable migraine days (month 1: $140 \mathrm{mg},-2.7 ; 280 \mathrm{mg}$, -3.0; placebo, -1.6; $P<0.05$ ) [42]. In both studies elevation of serum alanine aminotransferase was observed in a proportion of patients $(2.5 \%$, when the drug is taken daily), indicating safety concerns.

\section{Neurostimulation}

Invasive and non-invasive central or peripheral neurostimulation techniques have been developed by different companies with encouraging results for various headache disorders, including migraine and cluster headache. Recently the Neuromodulation Appropriateness Consensus Committee concluded that extracranial nerve stimulation should be considered in the algorithmic treatment of migraine [43]. To date there is evidence that only two non-invasive techniques are effective in migraine prevention: transcutaneous supraorbital and supratrochlear nerve stimulation (tSNS) and vagus nerve stimulation (VNS). Invasive techniques are also under investigation, yet they target non-responders to the currently available therapies in chronic migraine and in chronic cluster headache; but will not discussed here, even though they appear effective in early trials [44].

\section{Transcutaneous supratrochlear nerve stimulation (tSNS)}

The efficacy and safety of tSNS for prevention of episodic migraine has been evaluated in a randomized, doubleblind, sham-controlled trial published in Neurology [45]. Sixty-seven patients were treated with daily tSNS or sham sessions for 20 minutes per day for 3 months. The change in migraine days per month from baseline was significantly better in tSNS patients than in sham-treated patients $(-2.06, P=0.023$ vs. $-0.32, P=0.608)$ and had a $50 \%$ responder rate $(38.1 \%$ vs. $12.1 \%, P=0.023$, NNT = 3.8). Importantly, the primary endpoint of change in migraine days per month just missed significance in the intention-to-treat group $(P=0.054)$ and was not significantly different in per protocol analysis $(P=0.06)$ in the comparison between groups (tSNS and sham-treated). Rescue migraine medication intake was significantly reduced in the verum but not in the sham group. Notably, patients did not report many AEs [45]. It should be noted that it was difficult to completely blind this study. Although not reported in the study, personal reports from several patients using the device indicated that the paresthesias were strong enough to cause unblinding and discontinuation from the trial. In an observational survey among 2,313 patients, 54.4\% were satisfied with the treatment. Only $4.3 \%$ of individuals reported one or more AEs, such as local pain/intolerance to paresthesia $(2.03 \%)$, arousal changes $(0.82 \%)$ and headache after the stimulation $(0.52 \%)$. A transient local skin allergy was seen only in $0.09 \%$ [46]. In a second uncontrolled, observational study of patients suffering from episodic migraine without aura, a 2-month treatment with Cefaly (Cefaly Technology, Grâce-Hollogne, Belgium) significantly reduced migraine days per month compared to the baseline period, without reported AEs [47].

\section{Transcutaneous vagal nerve stimulation (tVNS)}

In a randomized, sham-controlled pilot study for prevention of chronic migraine with transcutaneous vagal nerve stimulation (tVNS) using the gammaCore stimulator (three daily 90-second stimulations for 2 months) the responder ratio was $15 \%$ (4 out of 26) in the verum group compared to zero (none out of 23) in the sham-stimulated group $(\mathrm{NNT}=6.7)$ [48]. This beneficial effect was confirmed in the subsequent open-label phase [49]. Besides neck muscle (platysma) contractions in some patients, there were no significant AEs. Apart from these preliminary data, further studies are needed to determine the role of tVNS in migraine prevention. Recent data indicate good efficacy for the symptomatic treatment of both migraine and cluster headache, and also for the prevention of cluster headache $[50,51]$.

\section{Sphenopalatine ganglion stimulation}

Sphenopalatine ganglion stimulation is under investigation for the symptomatic and preventive treatment of 
both migraine and cluster headache. When used acutely for attacks in patients with chronic cluster headache, many attacks significantly improve within 15 minutes, which was the primary endpoint. Some patients also experience a decrease in frequency of attacks over time. The device is available in Europe and has a CE mark (a CE mark is a logo that is placed on medical devices to show they conform to the requirements of the Medical Device Directive; it shows that the device is fit for its intended purpose as stated and meets legislation relating to safety; and it shows the product can be freely marketed anywhere in the European Union without further control). It is more invasive than tVNS, since implantation of the device through the oral cavity under general anesthesia is required [52].

\section{Transcranial magnetic stimulation}

There are data indicating that high-rate, repetitive transcranial magnetic stimulation is effective in migraine prevention [53], but further investigation is needed.

In general, these preliminary data of non-invasive neurostimulation in migraine prevention and symptomatic treatment of attacks in chronic cluster headache point towards a safety advantage, but whether they will be efficacious enough is yet to be determined. Additionally, neurostimulation may be a much better treatment option for migraineurs that do not stay on oral medications due to a variety of factors, such as pharmacophobia and nocebo behaviors. There are many studies of invasive implanted stimulators for chronic migraine and other headaches that are not discussed here.

\section{Conclusions}

Migraine is a common, chronic neurovascular disorder of the brain with cranial autonomic findings. It is characterized by recurrent, severe attacks of headaches often associated with other symptoms and much disability, as well as personal, familial and societal impact. Currently, there only are a limited number of preventive treatments for migraine worldwide, and they often are ineffective and cause AEs leading to low retention rates. Better therapies are badly needed. CGRP-mAbs to the ligand and receptor display at least, if not greater, comparable efficacy to the currently available oral therapies, with better safety data and perhaps adherence in phase 2 trials. Neurostimulation also appears promising, despite the limited evidence. Both monoclonal antibodies and neurostimulation appear to offer effective, novel management for migraine prevention and acute care of chronic cluster headache. We look forward to further results of these above therapies.

\section{Competing interests}

DDM has received honoraria, travel expenses and advisory board fees from Bayer Hellas, Genesis Pharma, Eli Lilly, Genzyme Hellas, Merck-Serono Hellas, Novartis Hellas and Teva. AMR is a speaker for Depomed and Teva; consults for Avanir, Depomed, Doctor Reddy's, ElectroCore, Impax, Pernix, Teva and Zosano; and does not currently perform clinical trials.

\section{Authors' contributions}

DDM and AMR participated in the literature search, preparation of the tables and writing of the manuscript. Both authors read and approved the final manuscript.

\section{Author details}

${ }^{1}$ Neurology Department, Athens Naval Hospital, 70 Dinokratous Street, 11521 Athens, Greece. ${ }^{2}$ The David Geffen School of Medicine at UCLA, Los Angeles, CA 90095, USA. ${ }^{3} 4255$ Jefferson Avenue, Suite 27, Woodside, California, CA 94062, USA.

Received: 7 July 2015 Accepted: 2 November 2015

Published online: 10 November 2015

\section{References}

1. Lipton RB, Bigal ME, Diamond M, Freitag F, Reed ML, Stewart WF, et al. Migraine prevalence, disease burden, and the need for preventive therapy. Neurology. 2007;68:343-9.

2. Lantéri-Minet M, Duru G, Mudge M, Cottrell S. Quality of life impairment, disability and economic burden associated with chronic daily headache, focusing on chronic migraine with or without medication overuse: a systematic review. Cephalalgia. 2011;31:837-50.

3. Mitsikostas DD, Thomas AM. Comorbidity of headache and depressive disorders. Cephalalgia. 1999;19:211-7.

4. Headache Classification Committee of the International Headache Society (IHS). The International Classification of Headache Disorders, 3rd edition (beta version). Cephalalgia. 2013;33:629-808.

5. Lipton RB, Silberstein SD. Episodic and chronic migraine headache: breaking down barriers to optimal treatment and prevention. Headache. 2015;55 Suppl 2:103-22. quiz 123-6.

6. Abu Bakar N, Tanprawate S, Lambru G, Torkamani M, Jahanshahi M, Matharu M. Quality of life in primary headache disorders: a review. Cephalalgia. 2015. [Epub ahead of print].

7. Erdélyi-Bótor S, Aradi M, Kamson DO, Kovács N, Perlaki G, Orsi G, et al. Changes of migraine-related white matter hyperintensities after 3 years: a longitudinal MRI study. Headache. 2015;55:55-70.

8. Global Burden of Disease Study 2013 Collaborators. Global, regional, and national incidence, prevalence, and years lived with disability for 301 acute and chronic diseases and injuries in 188 countries, 1990-2013: a systematic analysis for the Global Burden of Disease Study 2013. Lancet. 2015;386(9995):743-800.

9. Steiner TJ, Birbeck GL, Jensen RH, Katsarava Z, Stovner LJ, Martelletti P. Headache disorders are third cause of disability worldwide. J Headache Pain. 2015;16:58.

10. Silberstein SD, Holland S, Freitag F, Dodick DW, Argoff C, Ashman E, et al. Evidence-based guideline update: pharmacologic treatment for episodic migraine prevention in adults: report of the Quality Standards Subcommittee of the American Academy of Neurology and the American Headache Society. Neurology. 2012;78:1337-45.

11. Evers S, Afra J, Frese A, Goadsby PJ, Linde M, May A, et al. EFNS guideline on the drug treatment of migraine-revised report of an EFNS task force. Eur J Neurol. 2009;16:968-81.

12. Evers $\mathrm{S}$, Jensen R, European Federation of Neurological Societies. Treatment of medication overuse headache-guideline of the EFNS headache panel. Eur J Neurol. 2011;18:1115-21.

13. Dodick DW, Turkel CC, DeGryse RE, Aurora SK, Silberstein SD, Lipton RB, et al. OnabotulinumtoxinA for treatment of chronic migraine: pooled results from the double-blind, randomized, placebo-controlled phases of the PREEMPT clinical program. Headache. 2010;50:921-36.

14. Lipton RB, Silberstein S, Dodick D, Cady R, Freitag F, Mathew N, et al. Topiramate intervention to prevent transformation of episodic migraine: the topiramate INTREPID study. Cephalalgia. 2011;31:18-30.

15. Diener HC, Bussone G, Van Oene JC, Lahaye M, Schwalen S, Goadsby PJ, et al. Topiramate reduces headache days in chronic migraine: a randomized, double-blind, placebo-controlled study. Cephalalgia. 2007;27:814-23.

16. Grazzi L, Andrasik F. Non-pharmacological approaches in migraine prophylaxis: behavioral medicine. Neurol Sci. 2010;31 Suppl 1:S133-5.

17. Linde M, Mulleners WM, Chronicle EP, McCrory DC. Valproate (valproic acid or sodium valproate or a combination of the two) for the prophylaxis of episodic migraine in adults. Cochrane Database Syst Rev. 2013;6:CD010611. 
18. Linde M, Mulleners WM, Chronicle EP, McCrory DC. Topiramate for the prophylaxis of episodic migraine in adults. Cochrane Database Syst Rev. 2013;6:CD010610.

19. Luykx J, Mason M, Ferrari MD, Carpay J. Are migraineurs at increased risk of adverse drug responses? A meta-analytic comparison of topiramate-related adverse drug reactions in epilepsy and migraine. Clin Pharmacol Ther. 2009;85:283-8.

20. Gracia-Naya M, Santos-Lasaosa S, Ríos-Gómez C, Sánchez-Valiente S, GarcíaGomara MJ, Latorre-Jiménez AM, et al. Predisposing factors affecting drop-out rates in preventive treatment in a series of patients with migraine. Rev Neurol. 2011:53:201-8

21. Mitsikostas DD, Mantonakis LI, Chalarakis NG. Nocebo is the enemy, not placebo. A meta-analysis of reported side effects after placebo treatment in headaches. Cephalalgia. 2011;31:550-61.

22. Mitsikostas DD. Nocebo in headaches: implications for clinical practice and trial design. Curr Neurol Neurosci Rep. 2012;12:132-7.

23. Hepp Z, Dodick DW, Varon SF, Gillard P, Hansen RN, Devine EB. Adherence to oral migraine-preventive medications among patients with chronic migraine. Cephalalgia. 2015;35:478-88.

24. Karsan N, Goadsby PJ. CGRP mechanism antagonists and migraine management. Curr Neurol Neurosci Rep. 2015;15:25.

25. Zeller J, Poulsen KT, Sutton JE, Abdiche YN, Collier S, Chopra R, et al. CGRP function-blocking antibodies inhibit neurogenic vasodilatation without affecting heart rate or arterial blood pressure in the rat. Br J Pharmacol. 2008;155:1093-103.

26. Juhl L, Edvinsson L, Olesen J, Jansen-Olesen I. Effect of two novel CGRP-binding compounds in a closed cranial window rat model. Eur J Pharmacol. 2007;567:117-24.

27. Walter S, Alibhoy A, Escandon R, Bigal ME. Evaluation of cardiovascular parameters in cynomolgus monkeys following IV administration of LBR-101, a monoclonal antibody against calcitonin gene-related peptide. MAbs. 2014;6:871-8.

28. Bigal ME, Walter S, Rapoport AM. Calcitonin gene-related peptide (CGRP) and migraine current understanding and state of development. Headache. 2013;53:1230-44.

29. Descotes J. Immunotoxicity of monoclonal antibodies. MAbs. 2009;1:104-11.

30. Bigal ME, Walter S, Bronson M, Alibhoy A, Escandon R. Cardiovascular and hemodynamic parameters in women following prolonged CGRP inhibition using LBR-101, a monoclonal antibody against CGRP. Cephalalgia. 2014:34:968-76.

31. Bigal ME, Escandon R, Bronson M, Walter S, Sudworth M, Huggins JP, et al. Safety and tolerability of LBR-101, a humanized monoclonal antibody that blocks the binding of CGRP to its receptor: results of the Phase 1 program. Cephalalgia. 2013;34:483-92.

32. Dodick DW, Goadsby PJ, Silberstein SD, Lipton RB, Olesen J, Ashina M, et al. Safety and efficacy of ALD403, an antibody to calcitonin gene-related peptide, for the prevention of frequent episodic migraine: a randomized, double-blind, placebo-controlled, exploratory phase 2 trial. Lancet Neurol. 2014;13:1100-7.

33. Dodick DW, Goadsby PJ, Spierings EL, Scherer JC, Sweeney SP, Grayzel DS. Safety and efficacy of LY2951742, a monoclonal antibody to calcitonin gene-related peptide, for the prevention of migraine: a phase 2, randomized, double-blind, placebo-controlled study. Lancet Neurol. 2014;13:885-92.

34. Lenz R, Silberstein S, Dodick D, Reuter U, Ashina M, Saper J, et al. Results of a randomized, double-blind, placebo-controlled, phase 2 study to evaluate the efficacy and safety of AMG 334 for the prevention of episodic migraine. Valencia: 17th Congress of the International Headache Society; 2015.

35. Bigal ME, Dodick DW, Rapoport AM, Silberstein SD, Ma Y, Yang R, et al. Safety, tolerability, and efficacy of TEV-48125 for preventive treatment of high-frequency episodic migraine: a multicentre, randomised, double-blind, placebo-controlled, phase 2b study. Lancet Neurol. 2015;14(11):1081-90.

36. Bigal ME, Edvinsson L, Rapoport AM, Lipton RB, Spierings EL, Diener HC, et al. Safety, tolerability, and efficacy of TEV-48125 for preventive treatment of chronic migraine: a multicentre, randomised, double-blind, placebo-controlled, phase 2b study. Lancet Neurol. 2015;14(11):1091-100.

37. Shamliyan TA, Choi JY, Ramakrishnan R, Miller JB, Wang SY, Taylor FR, et al. Preventive pharmacologic treatments for episodic migraine in adults. J Gen Intern Med. 2013;28:1225-37.

38. Bertolotto $A$. Evaluation of the impact of neutralizing antibodies on IFN $\beta$ response. Clin Chim Acta. 2015;449:31-6.
39. Seng EK, Rains JA, Nicholson RA, Lipton RB. Improving medication adherence in migraine treatment. Curr Pain Headache Rep. 2015;19(6):498.

40. Berger A, Bloudek LM, Varon SF, Oster G. Adherence with migraine prophylaxis in clinical practice. Pain Pract. 2012;12:541-9.

41. Ho TW, Ho AP, Ge YJ, Assaid C, Gottwald R, MacGregor EA, et al. Randomized controlled trial of the CGRP receptor antagonist telcagepant for prevention of headache in women with perimenstrual migraine. Cephalalgia. 2015. [Epub ahead of print].

42. Ho TW, Connor KM, Zhang Y, Pearlman E, Koppenhaver J, Fan X, et al. Randomized controlled trial of the CGRP receptor antagonist telcagepant for migraine prevention. Neurology. 2014;83:958-66.

43. Deer TR, Mekhail N, Petersen E, Krames E, Staats P, Pope J, et al. The appropriate use of neurostimulation: stimulation of the intracranial and extracranial space and head for chronic pain. Neuromodulation Appropriateness Consensus Committee. Neuromodulation. 2014;17:551-70.

44. Ambrosini A, D'Alessio C2, Magis D, Schoenen J. Targeting pericranial nerve branches to treat migraine: Current approaches and perspectives. Cephalalgia. 2015. [Epub ahead of print].

45. Schoenen J, Vandersmissen B, Jeangette S, Herroelen L, Vandenheede M, Gérard P, et al. Migraine prevention with a supraorbital transcutaneous stimulator: A randomized controlled trial. Neurology. 2013;80:697-704.

46. Magis D, Sava S, d'Elia TS, Baschi R, Schoenen J. Safety and patients' satisfaction of transcutaneous supraorbital neurostimulation (tSNS) with the Cefaly device in headache treatment: A survey of 2,313 headache sufferers in the general population. J Headache Pain. 2013;14:95.

47. Russo A, Tessitore A, Conte F, Marcuccio L, Giordano A, Tedeschi G. Transcutaneous supraorbital neurostimulation in "de novo" patients with migraine without aura: the first Italian experience. J Headache Pain. 2015;16:69.

48. Silberstein SD, Neves da Silva A, Calhoun AH, Grosberg BM, Lipton RB, Cady RK, et al. Non-invasive vagus nerve stimulation for chronic migraine prevention in a prospective, randomized, sham-controlled pilot study (the EVENT study): report from the double-blind phase. Late breaking poster 19. Los Angeles, CA: 56th Annual Scientific Meeting of the American Headache Society; 2014. p. 26-9.

49. Silberstein SD, Neves da Silva A, Calhoun AH, Grosberg BM, Lipton RB, Cady RK, et al. Chronic migraine prevention with non-invasive vagus nerve stimulation in a prospective pilot study (the EVENT study): report from the open-label phase. Late breaking poster 21. Los Angeles, CA: 56th Annual Scientific Meeting of the American Headache Society; 2014. p. 26-9.

50. Nesbitt AD, Marin JC, Tompkins E, Ruttledge MH, Goadsby PJ. Initial use of a novel noninvasive vagus nerve stimulator for cluster headache treatment. Neurology. 2015;84:1249-53.

51. Gaul C, Diener HC, Silver N, Magis D, Reuter U, Andersson A, et al. Non-invasive vagus nerve stimulation for PREVention and Acute treatment of chronic cluster headache (PREVA): a randomised controlled study. Cephalalgia. 2015. [Epub ahead of print].

52. Schoenen J, Jensen RH, Lantéri-Minet M, Láinez MJ, Gaul C, Goodman AM, et al. Stimulation of the sphenopalatine ganglion (SPG) for cluster headache treatment. Pathway $\mathrm{CH}-1$ : a randomized, sham-controlled study. Cephalalgia. 2013;33:816-30.

53. Misra UK, Kalita J, Bhoi SK. High-rate repetitive transcranial magnetic stimulation in migraine prophylaxis: a randomized, placebo-controlled study. J Neurol. 2013;260:2793-801.

\section{Submit your next manuscript to BioMed Central and take full advantage of:}

- Convenient online submission

- Thorough peer review

- No space constraints or color figure charges

- Immediate publication on acceptance

- Inclusion in PubMed, CAS, Scopus and Google Scholar

- Research which is freely available for redistribution 